\title{
Distribution and production of plankton communities in the subtropical convergence zone of the Sargasso Sea. II. Protozooplankton and copepods
}

\author{
Nikolaj G. Andersen ${ }^{1,4}$, Torkel Gissel Nielsen ${ }^{1,2, *}$, Hans Henrik Jakobsen ${ }^{2,1}$, \\ Peter Munk ${ }^{2}$, Lasse Riemann ${ }^{3,4}$ \\ ${ }^{1}$ National Environmental Research Institute, Aarhus University, Department of Marine Ecology, 4000 Roskilde, Denmark \\ ${ }^{2}$ National Institute of Aquatic Resources, DTU Aqua Section for Oceanecology and Climate, \\ Technical University of Denmark, DTU Kavalergården 6, 2920 Charlottenlund, Denmark \\ ${ }^{3}$ Department of Natural Sciences, Linnaeus University, 39182 Kalmar, Sweden \\ ${ }^{4}$ Marine Biological Section, University of Copenhagen, Strandpromenaden 5, 3000 Helsingør, Denmark
}

\begin{abstract}
The oligotrophic Sargasso Sea in the western part of the North Atlantic Ocean is influenced by a complex set of oceanographic features that might introduce nutrients and enhance productivity in certain areas. To increase our understanding of the variability in plankton communities and to determine the potential reasons why Atlantic eels Anguilla spp. use this area for spawning, we investigated the distribution and productivity of the zooplankton community across the Subtropical Convergence Zone (STCZ) in the Sargasso Sea in March and April 2007. The vertical and horizontal distributions of protozoans and metazooplankton were investigated at 33 stations along 3 north to south transects ranging from 64 to $70^{\circ} \mathrm{W}$ to a depth of $400 \mathrm{~m}$. Copepods dominated the metazooplankton, while heterotrophic athecate dinoflagellates dominated the protozoan biomass. Other important groups were appendicularians, gastropod larvae and ostracods. Most of the recorded metazoan groups responded numerically to the frontal features (i.e. the surfacing of the isotherms) with high abundance in the STCZ compared with areas north and south of this. Juvenile copepod growth and egg production peaked in the STCZ, with a weight-specific growth rate of juvenile copepods ranging from 0.09 to $0.21 \mathrm{~d}^{-1}$, and a much lower specific egg production in the order of $0.01 \% \mathrm{~d}^{-1}$. The Sargasso Sea is described as oligotrophic, but the availability of athecate dinoflagellates and ciliates in the STCZ potentially leads to an enhanced mesozooplankton secondary production, which may in turn be available to organisms at higher trophic levels such as larvae of Atlantic eels.
\end{abstract}

KEY WORDS: Sargasso Sea · Ciliates $\cdot$ Heterotrophic dinoflagellates $\cdot$ Copepods $\cdot$ Convergence zone Resale or republication not permitted without written consent of the publisher

\section{INTRODUCTION}

Generally, nutrient-rich marine areas support classical food chains with a broad autotrophic base dominated by large phytoplankton and copepods. In contrast, oligotrophic waters, often strongly stratified, are dominated by small phytoplankton and high relative heterotrophic biomasses (Gasol et al. 1997) and the food web structure is more complex. However, such generalizations may be challenged by specific hydro- graphic features such as mesoscale eddies in the open oligotrophic oceans, which lead to extensive spatial variability and intermittency in production and assemblage structure of the plankton (Platt et al. 1989). Hence, such oceanic regions should not be considered homogeneous in space and constant in time.

The Sargasso Sea is an oligotrophic region in the western part of the North Atlantic Ocean surrounded by ocean currents. The biological system is influenced by complex patterns of thermal fronts (e.g. Voorhis \& 
Hersey 1964), irregular mesoscale eddies (McGillicuddy et al. 1998, Eden et al. 2009), advective transport of water masses (Palter et al. 2005) and a seasonal convective overturn (Hansell \& Carlson 2001), all of these leading to spatio-temporal variability in planktonic productivity. While the Bermuda Atlantic Time-Series Study (BATS) site is among the most intensively studied marine sites in the world (Steinberg et al. 2001), data on horizontal and vertical variability in plankton biomass, composition and productivity of the southern Sargasso Sea is limited.

The subtropical convergence zone (STCZ) is a characteristic oceanographic feature that borders the southern part of the Sargasso Sea. There, cold waters from the north meet warm tropical waters from the south (Voorhis \& Hersey 1964, Halliwell et al. 1994). Previous studies on abundance and distribution of mesozooplankton in the Sargasso Sea have focused on areas north of the STCZ (Deevey 1971, Deevey \& Brooks 1971, Madin et al. 2001). Only a few studies have covered the STCZ (Colton et al. 1975, Böttger 1982), and these showed north to south differences in abundance and biomass in the mesozooplankton communities. However, in these studies the food web characteristics were not related to the physical characteristics of the STCZ, and in general the physicalbiological linkages in this area are poorly understood.

The southern Sargasso Sea is the spawning site of the declining populations of Atlantic eels, the American eel Anguilla rostrata and the European eel A. anguilla, of which the European eel population is at a historical low level (ICES 2006). Consequently, there is motivation for improved understanding of ecological processes that supports the early life of the Atlantic eels in this region (Munk et al. 2010). Early studies suggested that the prey of eel larvae includes larvacean houses and zooplankton faecal pellets (Mochioka \& Iwamizu 1996), but recent data suggest that the diet encompasses a wide range of plankton organisms, including gelatineous zooplankton and copepods (Riemann et al. 2010).

Copepods account for 75 to $87 \%$ of mesozooplankton abundance in the upper $500 \mathrm{~m}$ of the Sargasso Sea (Böttger 1982). They primarily graze on microplankton $(>20 \mu \mathrm{m})$ and to a lesser extent on nanoplankton (>2 $\mu \mathrm{m}$ ) (Berggreen et al. 1988, Calbet \& Landry 1999, Calbet et al. 2000). The protozoans therefore play a prominent role in oligotrophic seas, re-packaging the primary producers dominated by picoplankton (2 to $0.2 \mu \mathrm{m}$ ) into size parcels available for the copepods. Investigations near Bermuda show that the biomass of ciliates and dinoflagellates is comparable with other oligotrophic areas (Lessard \& Murrell 1996) and that the grazing by the microzooplankton of primary producers (i.e. $<20 \mu \mathrm{m}$ ) is substantial (Lessard \& Murrell
1998). However, as stated above, productivity in the Bermuda area is not likely to be representative of conditions within the STCZ.

The aim of the present study was to investigate linkages between plankton dynamics and the oceanographic features characteristic of the southern Sargasso Sea. We hypothesized that the physical processes in the STCZ enhance proto- and metazooplankton production and biomass in this zone. In an accompanying paper, we investigated the primary and secondary production of the phyto- and picoplankton (Riemann et al. 2011, this volume).

\section{MATERIALS AND METHODS}

Study area. The investigation was conducted on board the Danish Navy surveillance frigate 'F359 Vædderen' during the Danish Galathea 3 Expedition. Sampling took place from March 29 to April 10, 2007, in the Sargasso Sea. On 3 cross-frontal transects along the longitudes $64^{\circ} \mathrm{W}, 67^{\circ} \mathrm{W}$ and $70^{\circ} \mathrm{W}, 33$ stations were sampled (see Fig. 1 in Riemann et al. 2011, this volume). The vertical distribution of salinity and temperature was measured down to $400 \mathrm{~m}$ with a CTD (Seabird 9/11) equipped with a 12 Niskin bottle 301 rosette sampler. In addition, the CTD was equipped with a fluorometer (SCUFA Turner design). Water samples from 10, 30, 60, 100, 200 and $400 \mathrm{~m}$ were taken at all stations. After collection, the water was kept dark and immediately brought to a temperature controlled laboratory container, where subsamples were taken for further analyses.

Protozoan biomass. Samples were collected from $10 \mathrm{~m}$ depth and from the fluorescence maximum. Immediately after the CTD rosette was on deck, a $300 \mathrm{ml}$ sample of seawater was fixed in acid Lugol's solution ( $2 \%$ final concentration). Samples were stored in the dark at $5^{\circ} \mathrm{C}$ and analysed within 3 months. Protozoans were enumerated and sized in $50 \mathrm{ml}$ Utermöhl settling chambers under an inverted microscope (Utermöhl 1958). Samples were allowed to settle for $24 \mathrm{~h}$ before microscopic examination. Cells were grouped into family, genera or species with the highest taxonomical resolution possible. Groups were subdivided into $10 \mu \mathrm{m}$ equivalent spherical diameter intervals and their volumes were estimated by means of appropriate morphology-derived volume relationship equations. We did not address chloroplasts in dinoflagellates; other studies indicate that dinoflagellate chloroplast pigment markers are absent in oligotrophic waters and the apparently autotrophic dinoflagellates are phagotrophic (Jeong et al. 2005, Schlüter et al. in press). We are thus confident that assigning heterotrophy to the athecate dinoflagellates of unknown trophy is a reasonable assumption. Cellular carbon content was estimated from the generic 
protozoan-specific volume:carbon regression given by Menden-Deuer \& Lessard (2000).

Protozoan secondary production. Maximal daily clearance rates were calculated from the group specific 'volume:clearance' equations by Hansen et al. (1997). We assumed maximal clearance $\left(C_{\max }\right.$, body volumes $\times 10^{5} \mathrm{~h}^{-1}$ ) because the in situ chlorophyll $a$ (chl a) concentration converted to carbon (carbon: chl a $=50$, Malone et al. 1993) was below the empirically determined $K_{\mathrm{m}}\left(2 \mathrm{ppm}=240 \mu \mathrm{g} \mathrm{C} \mathrm{l}^{-1}\right)$ from Hansen et al. (1997) as follows:

for ciliates: $\log C_{\max }=1.491-0.23 \log \left(P_{\mathrm{vol}}\right)$

for dinoflagellates: $\log C_{\max }=0.851-0.23 \log \left(P_{\mathrm{vol}}\right)$

where $P_{\mathrm{vol}}$ is the cell volume $\left(\mu \mathrm{m}^{3}\right)$. The rates were normalized to in situ temperature applying a $Q_{10}$ factor of 2.8 (Hansen et al. 1997). The ingestion was calculated from the size-specific clearance rates and the concentration of potential food, i.e. chl $a \times 50$. The protozoan

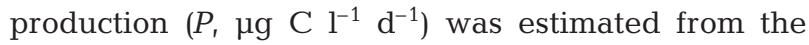
ingestion $(I)$ assuming a growth yield of 0.33 (Hansen et al. 1997):

$$
P=I \times 0.33
$$

Metazooplankton abundance. Vertical distribution of metazooplankton $>50 \mu \mathrm{m}$ in size was investigated at Transects 1 and 3 with a MultiNet Midi (HYDROBIOS) with an aperture of $0.25 \mathrm{~m}^{2}$. The MultiNet consists of 5 nets allowing the investigation of 5 strata: 0-50 m, 50-100 m, 100-200 m, 200-300 m and 300$400 \mathrm{~m}$, and 0-75 m, 75-150 m, 150-200 m, 200-300 m and $300-400 \mathrm{~m}$ at Transects 1 and 3, respectively. The MultiNet was lowered to $400 \mathrm{~m}$ and retrieved vertically at a speed of $10 \mathrm{~m} \mathrm{~min}^{-1}$. Samples were fixed in $4 \%$ formalin and stored at $5^{\circ} \mathrm{C}$. At Transect 2 and at 2 stations along Transect 3 , Stns $32\left(70^{\circ} \mathrm{W}, 29^{\circ} \mathrm{N}\right)$ and $33\left(70^{\circ} \mathrm{W}, 30^{\circ} \mathrm{N}\right)$, the MultiNet was not applied, and integrated abundance was only determined down to $250 \mathrm{~m}$. At these stations, a $45 \mu \mathrm{m}$ plankton net with an opening of $14 \mathrm{~cm}$, inserted inside a larger Mik-net, was used. This small net was also used at 5 other MultiNet stations. This approach made it possible to compare the efficiencies of the 2 nets, resulting in a factor of 1.2 applied to the catches of the small plankton net. Abundance estimates at $\operatorname{Stn} 31\left(28.0^{\circ} \mathrm{N}\right)$ were obtained from only 3 strata instead of 5, owing to failure of the MultiNet at that station.

Copepod and appendicularian biomass. Biomasses were calculated for 3 main groups: Paracalanus, Clausocalanus and Calocalanus spp. (referred to as calanoids), Oithona spp. and other copepods (referred to as others). During the identification and enumeration, the lengths of adults, copepodites and nauplii were measured for 10 (when possible) individuals of each species or genera at each station. Biomass for appendicularians were calculated for Oikopleura spp. and Fritillaria spp. (mean length $\pm \mathrm{SD}=254.3 \pm 37 \mu \mathrm{m}, \mathrm{n}=$ 172). Length-weight regressions representative of species morphologically similar to those in the present study were obtained from the literature (Table 1).

Copepod growth rate. Growth rates of the dominant copepodites were measured at 10 stations by the artificial cohort method (Tranter 1976, Kimmerer \& McKinnon 1987). Copepodites were collected with a $50 \mu \mathrm{m}$ WP-2 net. Two oblique hand tows were made vertically from ca. $30 \mathrm{~m}$ depth to the surface. The collected copepods were stored in an insulated tank containing surface water and processed in the following way. The sample was diluted with $50 \mu \mathrm{m}$ filtered surface seawater to obtain a concentration of $\sim 7$ to $8 \mathrm{l}^{-1}$ and then siphoned into a 101 collapsible polyethylene water container. A $200 \mu \mathrm{m}$ sieve was lowered into the bucket leaving organisms $>200 \mu \mathrm{m}$ outside. Water from inside of the sieve was siphoned to another submerged $160 \mu \mathrm{m}$ sieve. The submerged $160 \mu \mathrm{m}$ sieve was gently lifted and lowered while running surface water was added to the bucket outside the sieve. In that manner, organisms < 160 $\mu \mathrm{m}$ were flushed out of the bucket and the water inside the sieve then contained only an artificial cohort of copepodites between 160 and $200 \mu \mathrm{m}$ (mainly Stages C1 to C3). The water in the bucket was

Table 1. Length-weight regressions applied in the present study

\begin{tabular}{|lll|}
\hline Length-weight regression & Applied group & Reference \\
\hline$W=3.18 \times 10^{-6} L^{3.331}(\mathrm{ng} \mathrm{C}+\mu \mathrm{m})$ & Nauplii & Berggreen et al. (1988) \\
$\ln W=3.25 \ln L-19.65(\mu \mathrm{g}+\mu \mathrm{m})$ Weights and biomasses reported & $\begin{array}{l}\text { Paracalanus, Clausocalanus } \\
\text { and Calocalanus spp. }\end{array}$ & Chisholm \& Roff (1990) \\
here are room-equilibrated weights, i.e. dry weight $\times 1.06$ & Oithona spp. & Hopcroft et al. (1998a) \\
$\log W=3.16 \log L-8.18(\mu \mathrm{g}+\mu \mathrm{m})$ & Other calanoid species & Chisholm \& Roff (1990) \\
$\ln W=2.74 \ln L-16.41(\mu \mathrm{g}+\mu \mathrm{m})$ & Other cyclopoid species & Chisholm \& Roff (1990) \\
$\ln W=1.96 \ln L-11.64(\mu \mathrm{g}+\mu \mathrm{m})$ & Harpacticoid species & Satapoomin (1999) \\
$\ln W=1.15 \ln T L-7.79(\mu \mathrm{g} \mathrm{C}+\mu \mathrm{m})$ & Larvacean community & Jaspers et al. (2009) \\
$\log W=2.455 \log T L-6.96(\mu \mathrm{g} \mathrm{C}+\mu \mathrm{m})$ & &
\end{tabular}


then adjusted to obtain a concentration of $\sim 7$ to $8 \mathrm{l}^{-1}$. Then we took 7 samples of 11 each. Three start samples were concentrated on a $50 \mu \mathrm{m}$ mesh, rinsed into a $100 \mathrm{ml}$ container and fixed in $4 \%$ buffered formalin. The last 4 samples were transferred to four 51 plastic containers and 31 of $50 \mu \mathrm{m}$ filtered surface seawater was added. Before use, the plastic containers were repeatedly filled with surface water and left on deck exposed to full sunlight to remove potential contaminants. The containers were incubated under deck in a $1 \mathrm{~m}^{3}$ plastic container with running surface water. During the day the ship's hatches provided light, and dim light from the ship illuminated the containers at night. No attempt was made to reach a specific number of copepodites per container. After $24 \mathrm{~h}$ incubation, the samples were concentrated on a $50 \mu \mathrm{m}$ filter, checked for dead copepodites under a dissecting microscope (no mortality was observed) and fixed in $4 \%$ buffered formalin. The incubation temperature for each experiment is the mean of the start and final temperature $\left(\Delta \max , 2.2^{\circ} \mathrm{C}\right)$.

Prosome lengths (to articulation point with urosome) of the calanoids and Oithona spp. were measured with a stereo microscope (Olympus SZ40 Zoom) under 80× magnification. Up to 30 specimens of each taxon were counted per sample. Damaged organisms were not considered. After the samples were processed the copepodites were stored in $96 \%$ ethanol.

The fractionating process did not exclude particles $<160 \mu \mathrm{m}$ completely. Therefore, some nauplii could have metamorphosed into Stage C1 during incubation resulting in a lower calculated growth rate (Kimmerer et al. 2007). To account for this, the amount of $\mathrm{C} 1$ in the incubated samples was adjusted to the abundance of $\mathrm{C} 1$ in the start samples in cases with surplus C1 copepodites. Lengths were converted to weights using length-weight regressions before calculation of mean weight. The weight-specific growth rate $(\mu)$ per day was calculated as:

$$
\mu=24 / T \times \ln \left(\frac{W_{T}}{W_{0}}\right)
$$

where $T$ = incubation time in hours, $W_{0}=$ mean weight at the start of the incubation, $W_{T}=$ mean weight at the end of the experiment.

Except for Paracalanus, Clausocalanus and Calocalanus spp. at Stn 32, no significant differences in weight between the 3 start samples (Kruskal-Wallis test: $\mathrm{p}>0.05$ ) were observed. We calculated 4 growth rates from the 4 incubated samples at each station using the arithmetic mean of the 3 start samples as $W_{0}$. The final growth rate at each station is a mean of the 4 growth rates.

Copepod egg production. Copepod egg production was measured for Acartia sp. at 6 stations on each of
Transects 2 and 3. Acartia was chosen as indicator of secondary production (Kiørboe \& Johansen 1986) because Acartia's egg production actually reflects the food ingested during incubation (Tester \& Turner 1990). The copepods were sampled at the same time and by the same method as the copepods for growth rate experiments but with a $200 \mu \mathrm{m}$ WP-2 net. Adult female Acartia spp. were picked out with a large bore pipette and added to $600 \mathrm{ml}$ polycarbonate bottles with $50 \mu \mathrm{m}$ filtered surface seawater; 3 females were added per bottle and 3 to 5 replicate bottles were taken at each station. After $24 \mathrm{~h}$ incubation under the same conditions as the growth rate experiments, samples were filtered through a $50 \mu \mathrm{m}$ net and eggs and live and dead females were counted. Overall mortality was $<10 \%$ and dead females were omitted from any further calculations. The specific egg production (SEP, \% $\mathrm{d}^{-1}$ ) was calculated by:

$$
\mathrm{SEP}=\mathrm{EP} \times\left(\mathrm{C}_{\mathrm{e}} / \mathrm{C}_{\mathrm{f}}\right)
$$

where $\mathrm{EP}=$ no. eggs female $\mathrm{e}^{-1} \mathrm{~d}^{-1}, \mathrm{C}_{\mathrm{e}}=$ egg carbon content, $\mathrm{C}_{\mathrm{f}}=$ female carbon content. The carbon content of the eggs and females was estimated from the egg volume and a conversion factor of $0.14 \times 10^{-6} \mu \mathrm{g} \mathrm{C} \mathrm{mm}^{-3}$ (Kiørboe et al. 1985), and the length-weight regression in Berggreen et al. (1988), respectively.

Juvenile secondary production. The calculation of juvenile secondary production was based on biomasses and growth rates for the relevant groups. Biomasses were calculated for 5 assemblages (the calanoids and Oithona spp. used in the growth rate experiments and the rest of the calanoids, cyclopoids and harpacticoids) each divided into nauplii (Stages N1 to N6) and copepodites (Stages C1 to C5) giving biomasses for 10 groups. Growth rates for the calanoids and Oithona spp. were used at stations where they were measured.

Where juvenile growth rate was not measured, the mean values for the calanoids or Oithona spp. were applied to the relevant biomasses. Where growth rates for both groups where available the mean growth rate was applied to the rest of the juvenile copepods. Where only growth rate for one of the groups was measured, a mean of the measured growth rate and the overall mean of the other group (calanoids or Oithona) was used. At stations where no growth rates were available, an overall mean for the calanoids and Oithona spp. was used. Juvenile growth rates were transformed to percent (see Eq. 6) before production calculations.

$$
g_{j}=e^{\mu}-1
$$

where $g_{j}=$ juvenile specific growth rate $\left(\mathrm{d}^{-1}\right)$ and $\mu=$ specific growth rate $\left(\mathrm{d}^{-1}\right)$.

Adult secondary production. The production of adult copepods was calculated from adult biomasses of calanoids, Oithona spp. and the remaining calanoids, 
cyclopoids and harpacticoids. The specific egg production rates were applied to the relevant biomasses for each station. At stations where no egg production was available an overall mean was applied. Unidentified copepods were for both juvenile and adult biomasses divided proportionally to calanoids, cyclopoids and harpacticoids. At stations with missing biomass measurements no production was calculated. Total daily copepod production was estimated as the product of the copepod biomass and the specific growth:

$$
P=\left(g_{j} \times B_{j}\right)+\left(\mathrm{SEP} \times B_{a}\right)
$$

where $P=$ daily production $\left(\mathrm{mg} \mathrm{C} \mathrm{m} \mathrm{m}^{-2} \mathrm{~d}^{-1}\right), B_{j}=$ juvenile copepod biomass ( $\left.\mathrm{mg} \mathrm{C} \mathrm{m}^{-2}\right), g_{j}=$ juvenile specific growth rate $\left(\mathrm{d}^{-1}\right), \mathrm{SEP}=$ specific egg production $\left(\% \mathrm{~d}^{-1}\right)$ and $B_{a}=$ adult biomass. When comparing the contribution of juvenile growth to total copepod production, the copepod production was calculated assuming community-specific egg production to be representative for growth rates of all copepod stages (Berggreen et al. 1988).

Estimated secondary production. We compared our measured copepod secondary production with estimates made from using the backward step-wise multiple linear regression model of Hirst \& Bunker (2003), where the secondary production depends on the mean temperature in the upper $400 \mathrm{~m}\left(T,{ }^{\circ} \mathrm{C}\right)$, the total integrated body weight (BW) for 0 to $400 \mathrm{~m}$ of the copepod population $\left(\mathrm{mg} \mathrm{C} \mathrm{m}^{-2}\right)$ and the integrated chl a concen-

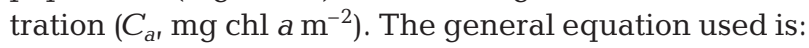

$$
\log _{10} g=a(T)+b\left(\log _{10} \mathrm{BW}\right)+c\left(\log _{10} C_{a}\right)+d
$$

The factors $a, b, c$ and $d$ are covering 'All data' and not changed according to the copepod category (adult, juvenile, broadcasters and egg-carrying copepods) (Table 4 in Hirst \& Bunker 2003).

Clearance rate. Ingestion rates were calculated from specific growth rate in juveniles and specific egg production in adults assuming an ingestion growth yield of $33 \%$. That is, ingestion rate equals secondary production rate multiplied by 3 (Berggreen et al. 1988). Before calculating ingestion, juvenile specific growth rate was transformed to percent (Eq. 6). Weights for the relevant species are an overall mean for all stations.

Clearance rate $(C)$ was subsequently calculated as:

$$
C=\left(\frac{I}{\mathrm{FC}}\right) \times 1000
$$

where $C=$ clearance rate $\left(\mathrm{ml}\right.$ ind.$\left.^{-1} \mathrm{~d}^{-1}\right), I=$ ingestion

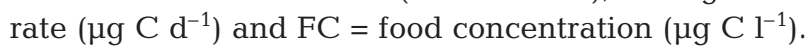
Juveniles were assumed to exploit phytoplankton and protozoans, while the adults were assumed to ingest protozoans and phytoplankton $>10 \mu \mathrm{m}$ (data on chl a fractions are presented in our companion paper, Riemann et al. 2011).
Carbon budgets. To summarize and compare the food web structure and the carbon cycling of the different water masses, carbon budgets were prepared within water masses of comparable oceanographic characteristics: (1) stations in the warm water masses $\left(>25^{\circ} \mathrm{C}\right)$ south of the front on Transect $1,(2)$ the STCZ between the 2 fronts and (3) the stations north of the fronts. The values of the budget represent biomasses and production and were estimated by trapezoidal integration of each discrete sampling depth down to $400 \mathrm{~m}$ depth where values were set to 0 .

\section{RESULTS}

\section{Oceanography}

At the southern regions of all 3 transects the water column was strongly stratified, in general with a thermocline at $\sim 150 \mathrm{~m}$ depth separating the warm surface water $\left(27\right.$ to $21^{\circ} \mathrm{C}$, south and north of the front, respectively) from colder subthermocline water $\left(18\right.$ to $\left.19^{\circ} \mathrm{C}\right)$ (Fig. $1 \mathrm{a}-\mathrm{c}$ ). Along Transect 1 , the thermocline inclined and isotherms from 75 to $125 \mathrm{~m}$ depth raised and formed a surface front. Further to the north, additional surfacing of isotherms was evident, resulting in a second front. North of this, the stratification of the water column was weaker. We interpret these 2 fronts, and the zone in between them as the STCZ. Transects 2 and 3 were not of the same horizontal coverage and did not fully cover the southernmost front. Transect 2 was located right in the STCZ. Surface temperature change along Transect 2 was only from 21 to $23^{\circ} \mathrm{C}$ (Fig. 1b). The northernmost part of Transect 3 passed the northern edge of the STCZ (Fig. 1c). Salinity ranged from 36 to 37 at all 3 transects (data not shown). At the southern section of Transect 1, a salinity-stratified layer in the 100 to $150 \mathrm{~m}$ strata was evident. From there, the salinity declined to 36 towards the surface and bottom. The halocline was less pronounced at the northern end of the transect, while at Transect 3, a halocline was only evident at the southernmost stations.

\section{Chl a fluorescence}

Distribution of chl a fluorescence was related to the physical characteristics of the water column. At Transects 1 and 2, a fluorescence maximum was located in the pycnocline at $\sim 125 \mathrm{~m}$ depth. Transect 3 also showed this subsurface fluorescence peak, but the maximum was located higher in the water column at the northernmost stations. A peak in the fluorescence at Transect 1 was seen slightly higher in the water column, $100 \mathrm{~m}$, at the northern end of the transect where the isotherms 

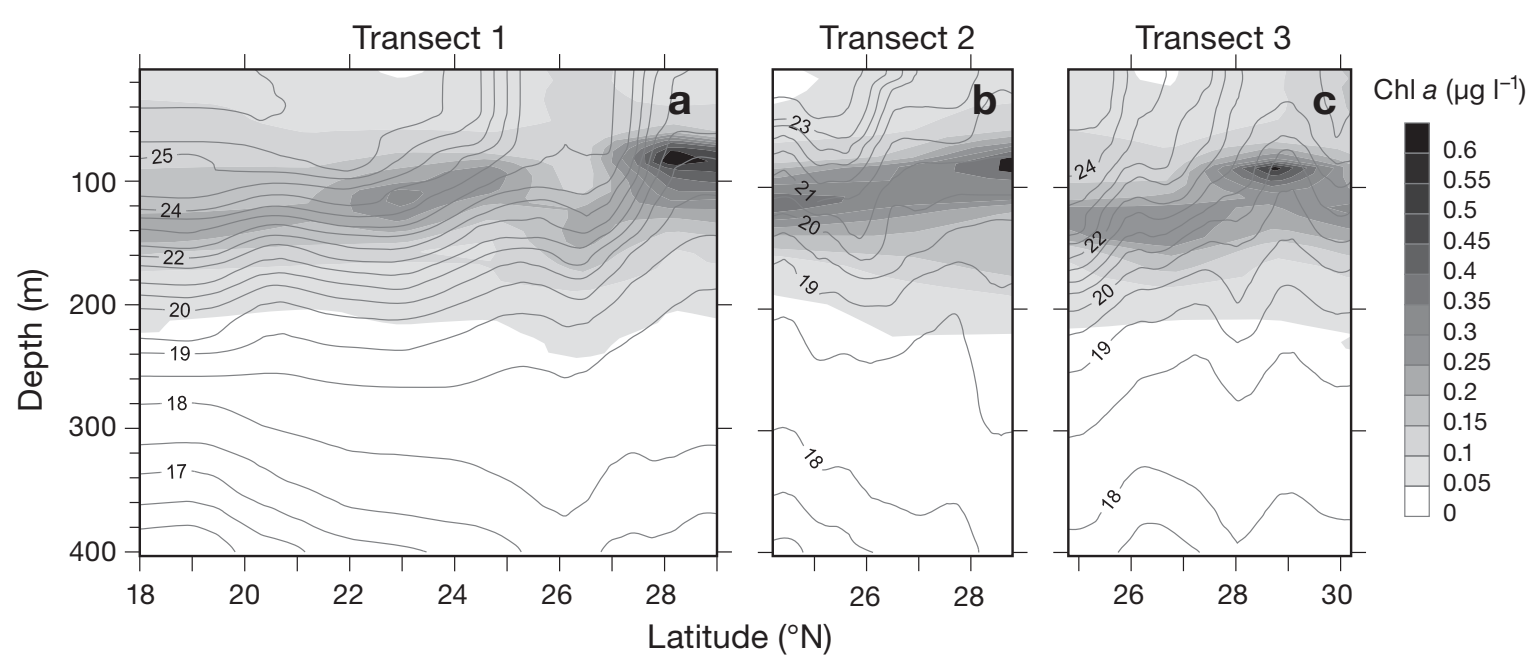

Fig. 1. $(\mathrm{a}, \mathrm{b}, \mathrm{c})$ Vertical distribution of temperature (isotherms, ${ }^{\circ} \mathrm{C}$ ) and $\mathrm{chl}$ a (shading, $\mu g \mathrm{l}^{-1}$ ) along the 3 transects

rose towards the surface (Fig. 1a). Along Transect 2, the fluorescence was seen around the pycnocline (Fig. 1b), and in Transect 1, the fluorescence maximum rose to $\sim 100 \mathrm{~m}$ towards the northern end of the transect.

\section{Protozoans}

The protozoans were separated into ciliates and hetero/mixotrophic dinoflagellates, which in turn were identified to genera, families or size classes. Among the dinoflagellates these groups were Cochlodinium sp. (average, $0.1 \times 10^{3}$ cells $\mathrm{l}^{-1}$ ), Gymnodinium spirale (average, $4 \times 10^{3}$ cells $\mathrm{l}^{-1}$ ) and unidentified athecate

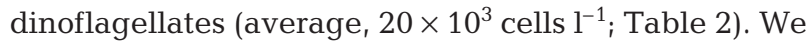
included athecate dinoflagellates with unknown trophy among the heterotrophs because heterotrophy appears to be the norm among dinoflagellates in open oligotrophic waters (Fig. 2a-c). (Schlüter et al. in press). The athecate dinoflagellate $G$. spirale was the most important protozoan species in terms of biomass,

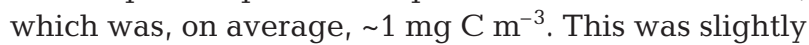
higher than the average biomass for the entire ciliate community. The most important protozoan group was unidentified athecate dinoflagellates, which accounted for almost $50 \%$ of the protozoan biomass. There was a similar concentration of unidentified athecate dinoflagellates at $10 \mathrm{~m}$ and at the fluorescence maximum (Table 2). However, owing to a larger cell size, the biomass of these was highest at $10 \mathrm{~m}$ depth.

Ciliates were less abundant at the surface (average, $0.6 \times 10^{3}$ cells $\mathrm{l}^{-1}$ ) than at the fluorescence maximum (average, $0.9 \times 10^{3} \mathrm{l}^{-1}$; Table 2). Cells $>30 \mu \mathrm{m}$ dominated the ciliate biomass at all transects, which was typically 0.5 to $1.5 \mathrm{mg} \mathrm{C} \mathrm{m}^{-3}$ with highest values occurring in the northern part of Transect 1 (Fig. 2d-f). The depth-integrated protozoan biomass was generally around $500 \mathrm{mg} \mathrm{C} \mathrm{m}^{-2}$ (range, 200 to $1600 \mathrm{mg} \mathrm{C} \mathrm{m}^{-2}$ ) with the highest values found at the northern part of Transect 1. The depth-integrated biomass of protozoans was dominated by heterotrophic dinoflagellates (Fig. $2 g-i$ ). The horizontal distribution of protozoans displayed limited spatial variation. Elevated protozoan biomass was only observed at one station at the northern part of Transect 1 in association with the surface front.

\section{Metazooplankton abundance and depth distribution}

Copepods accounted for $95 \pm 2 \%$ of the metazooplankton abundance. Other important groups where

Table 2. Abundance of the major protozoans $>4 \mu \mathrm{m}$. Zone means $\pm \mathrm{SD}$ (cells $\left.\mathrm{l}^{-1}\right)$ at the surface $(10 \mathrm{~m})$ and at the maximum fluorescence $\left(f_{\mathrm{max}}\right)$. STCZ = Subtropical Convergence Zone

\begin{tabular}{|c|c|c|c|c|c|c|c|c|}
\hline & $10 \mathrm{~m}$ & $f_{\max }$ & $10 \mathrm{~m}$ & $f_{\max }$ & $10 \mathrm{~m}$ & $f_{\max }$ & $10 \mathrm{~m}$ & $f_{\max }$ \\
\hline South of STCZ & $102 \pm 50$ & $124 \pm 69$ & $1650 \pm 898$ & $5446 \pm 1384$ & $21060 \pm 7456$ & $26455 \pm 10433$ & $704 \pm 429$ & $1613 \pm 1012$ \\
\hline North of STCZ & $109 \pm 49$ & $157 \pm 60$ & $4141 \pm 2375$ & $4889 \pm 2842$ & $16371 \pm 3171$ & $25080 \pm 11933$ & $545 \pm 452$ & $2121 \pm 1610$ \\
\hline
\end{tabular}




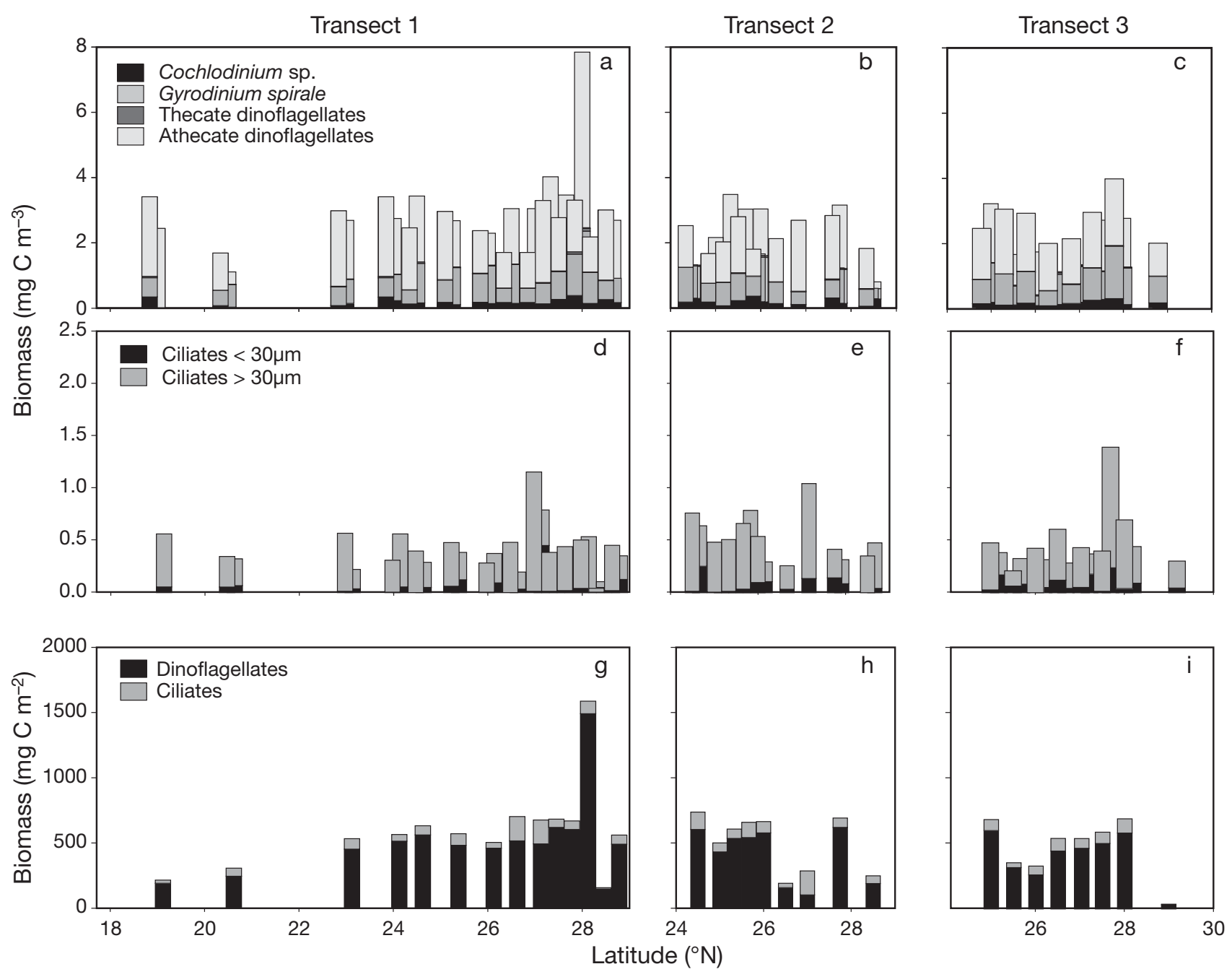

Fig. 2. (a-f) Biomass (mg C m${ }^{-3}$ ) at the surface (bars in the front) and subsurface (bars in the background). (a-c) Dinoflagellates, $(\mathrm{d}-\mathrm{f})$ ciliates. $(\mathrm{g}-\mathrm{i})$ Biomass of dinoflagellates and ciliates integrated to $400 \mathrm{~m}$ depth $\left(\mathrm{mg} \mathrm{C} \mathrm{m}^{-2}\right)$

appendicularians $(1.2 \pm 0.7 \%)$, gastropod larvae $(0.7 \pm$ $0.7 \%)$ and ostracods $(1.6 \pm 0.8 \%)$. The diversity of the copepod community was high, with 65 identified species belonging to 45 genera in 28 families (Fig. 3). Fisher's diversity index $( \pm \mathrm{SD})$ showed no significant difference between south $(4.6 \pm 0.6)$, the middle $(3.7 \pm 1.2)$ and north $(3.7 \pm 1.7)$ of the front (KruskalWallis 1-way ANOVA on Ranks, p = 0.591). We focused on the 3 calanoid genera (Clausocalanus, Paracalanus and Calocalanus) and Oithona spp., which accounted for $25 \pm 6 \%$ and $21 \pm 5 \%$ of the total copepod abundance, respectively.

The highest abundance of mesozooplankton was observed in the upper $200 \mathrm{~m}$ (Fig. 4). Across the STCZ considerable variation in the vertical and horizontal distributions of the major zooplankton groups were observed (Fig. 4). Within this stratum, a bimodal distribution pattern was observed for the zooplankton with 2 peaks, one in the surface layer and 1 around the subsurface fluorescence maximum. Along transects, there were higher abundances of the major zooplankton groups within the STCZ, in association with the subsurface phytoplankton bloom around $150 \mathrm{~m}$ depth. For the appendicularians, this pattern was particularly evident both at the surface and subsurface (Fig. 4g,h).

Resolving the vertical distribution of the copepod community to genus level revealed a diverse distribution pattern for the 5 most abundant genera. The 3 dominant genera (Clausocalanus spp., Calocalanus spp. and Microsetella spp.) had the highest abundance in the upper $50 \mathrm{~m}$ of the water column (Fig. 5a-f), while Oncaea and Oithona were present throughout the water column but with highest abundance around the subsurface peak (Fig. $5 \mathrm{~g}-\mathrm{j}$ ). The highest biomass occurred along Transect 2, but only at Transect 1 (which 


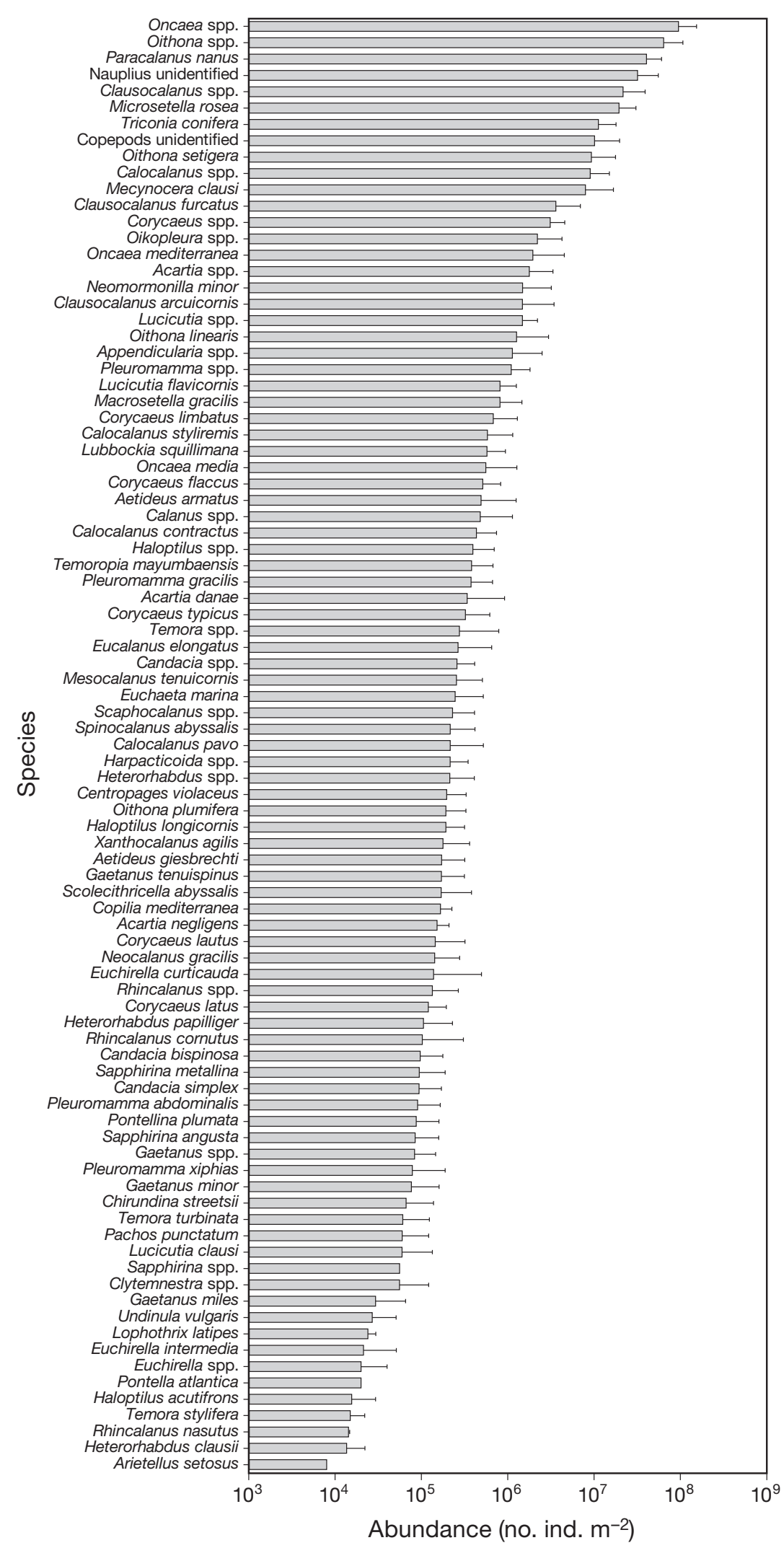

Fig. 3. Abundance (mean $\pm \mathrm{SD}$ ) of the identified copepod and appendicularian taxa. Integrated depth: $400 \mathrm{~m}$ at Transects 1 and 3,250 m at Transect 2 had a more extensive coverage of STCZ and adjacent areas) was there a clear tendency to elevated biomass within STCZ observed (Fig. 6). The integrated biomass (mean $\pm \mathrm{SD}$ ) for the 3 areas to the south, in the middle and to the north of the front were $260 \pm 46,329 \pm 211$ and $343 \pm 201 \mathrm{mg} \mathrm{C} \mathrm{m}^{-2}$, respectively.

\section{Growth rates and production}

The cyclopoid Oithona spp. and the calanoids (Clausocalanus, Paracalanus and Calocalanus) had specific growth rates of (mean $\pm \mathrm{SE}$ ) $0.09 \pm 0.08 \mathrm{~d}^{-1}$ and $0.21 \pm 0.08 d^{-1}$, respectively (Fig. $7 a-c$ ). The calanoid copepodites showed a tendency to highest growth rates at the middle of Transect 2 and the northern end of Transect 3. The Oithona spp. copepodites had the lowest growth rate in the middle of Transect 2 .

Specific egg production of Acartia sp. peaked at $0.02 \mathrm{~d}^{-1}$ (3 eggs female ${ }^{-1} \mathrm{~d}^{-1}$ ) on Transect 2 for Stns 20 and 21 (Fig. 7d). At Transect 3 the specific egg production was highest at the northern end, with a maximum of $0.01 \mathrm{~d}^{-1}$ (2 eggs female ${ }^{-1} \mathrm{~d}^{-1}$, Fig. 7e). Specific egg production and calanoid copepodite specific growth rates showed the highest rates at the same stations.

The production of adult copepods (Fig. 8a-c) was significantly lower than that of juveniles (Fig. 8d-f) (Student's t-test: $\mathrm{p}<0.01)$. A tendency to higher adult and juvenile production in the STCZ was observed at Transect 1 (Fig. 7). No tendency in production was detected along Transect 2, but Stn 19 for juveniles and Stn 21 for adults showed high production. At Transect 3, the production tended to rise for both juveniles and adults towards the north.

Compared with the measured secondary production rates, application of the Hirst \& Bunker (2003) equation overestimated the secondary production (sum of juvenile growth and specific egg production) by $20 \pm 2.6 \%$. Using specific egg production alone as a proxy for secondary production underestimated the production by ca. $92 \pm$ $0.1 \%$ (Table 3 ). 


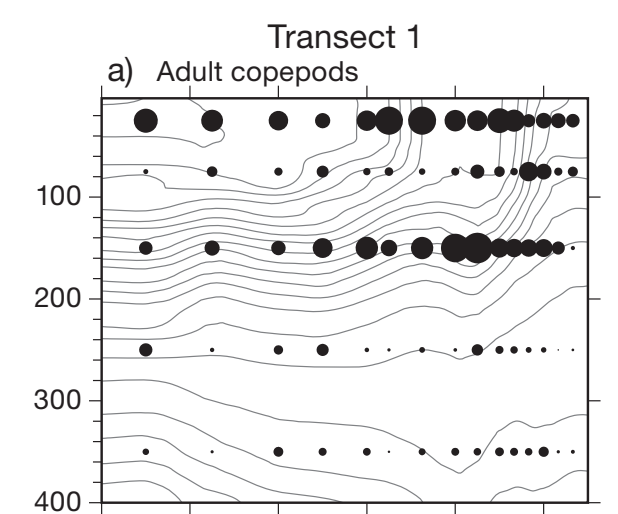

Transect 3

b) Adult copepods

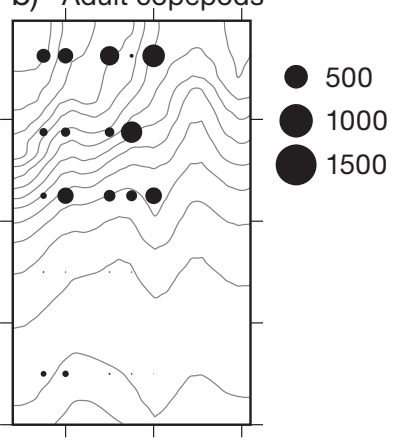

c) Copepodites

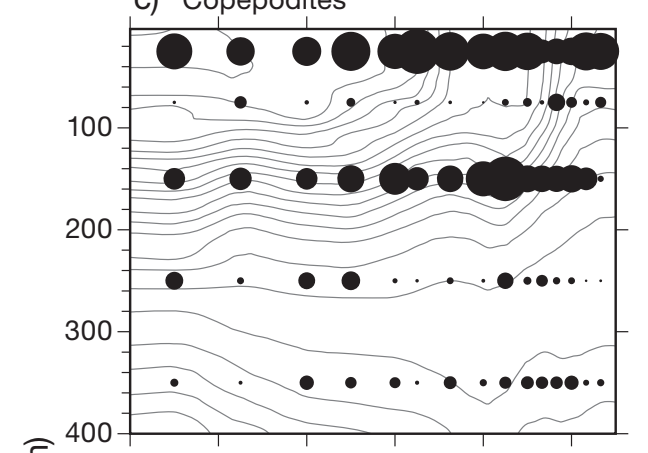

d) Copepodites

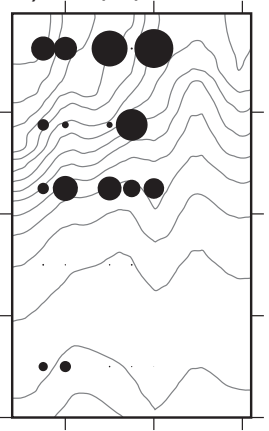

f) Nauplii

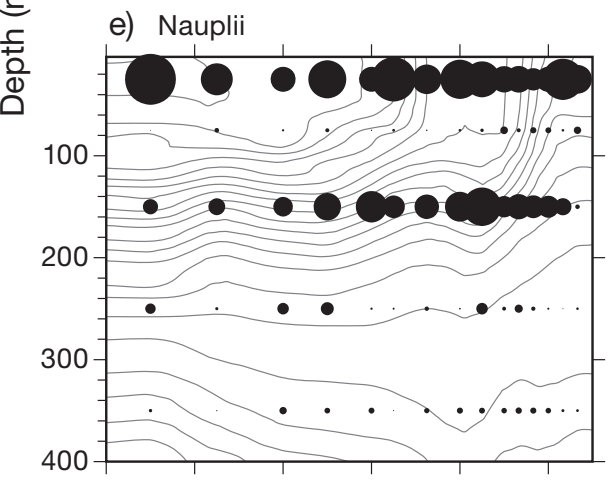

g) Appendicularians

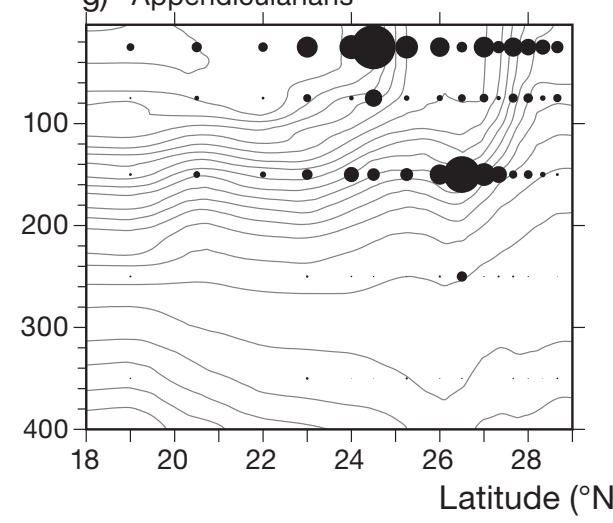

h) Appendicularians

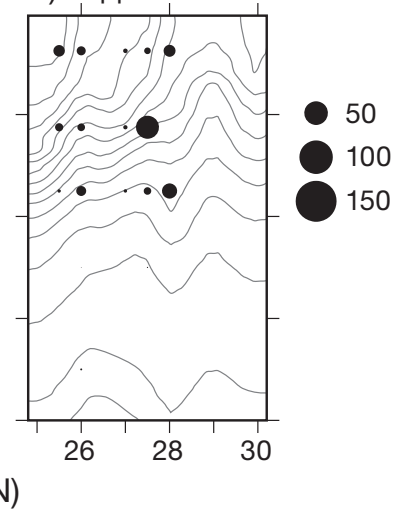

Fig. 4. Depth distribution of the metazooplankton community $\left(\mathrm{m}^{-3}\right)$ illustrated by relative area of circles along Transects 1 and 3, superimposed on the temperature distribution (isotherms). (a,b) Adult copepods, $(c, d)$ copepodites, $(e, f)$ nauplii and $(g, h)$ appendicularians

\section{Regional comparison}

No significant differences between the STCZ and the adjacent regions were observed, except for phytoplankton biomass, which was significantly higher in the northern region (1-way ANOVA: $p<0.001$ ), and bacterioplankton biomass, which was higher in the southern region (1-way ANOVA: p < 0.05), when comparing integrated biomass and production of the major trophic components in the upper $400 \mathrm{~m}$ (Fig. 9). The integrated biomass and production were dominated by bacteria and phytoplankton, respectively.

\section{DISCUSSION}

The present investigation of the plankton communities across the STCZ in the Sargasso Sea points to physicalbiological linkages related to the specific oceanography of the area. These relationships were apparent for the lowest trophic levels (Riemann et al. 2011) as well as for the rest of the plankton food web reported here. Protozoans such as ciliates and heterotrophic dinoflagellates were the most important grazers in the STCZ (Fig. 9b), representing a major trophic link between the picoplankton-based primary production and copepod grazers.

The stratification of the water column inside and outside of the STCZ had strong influence on the depth distribution of all trophic levels from phytoplankton to mesozooplankton. The pronounced subsurface peak (primarily of Prochlorococcus sp.) was located relatively deep in the water column in association with the pycnocline (Riemann et al. 2011). The subsurface chl a peak was reflected in associated elevated protozoan biomass (Table 2). The depth distribution of all copepods was bimodal with highest abundance in the surface layer and in the pycnocline where it corresponded to the distribution of chl a. In general, this bimodality was composed of different zooplankton communities, such that some copepod groups had their maximum in surface 


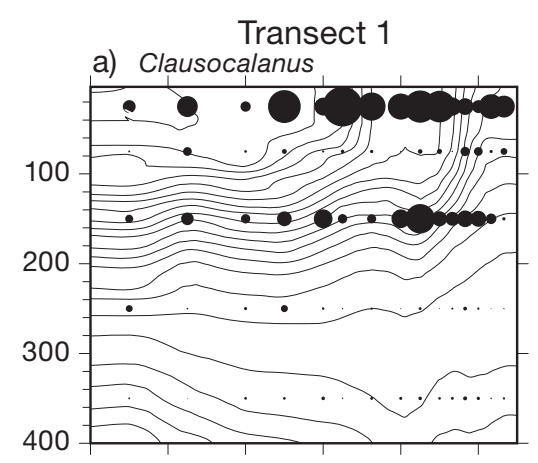

Transect 3

b) Clausocalanus

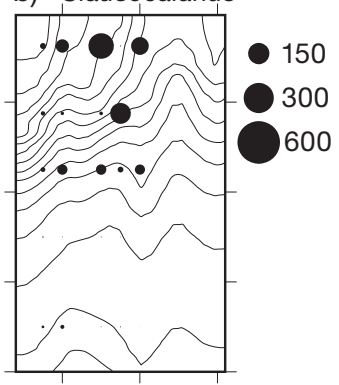

c) Calocalanus

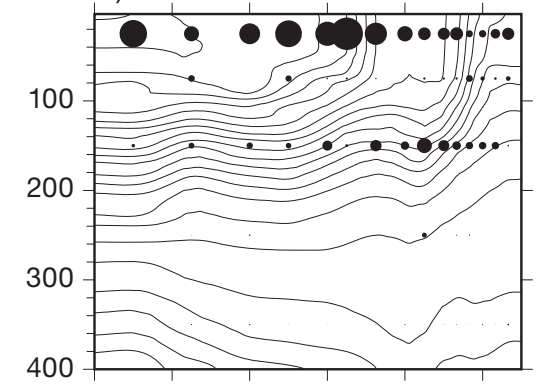

e) Microsetella

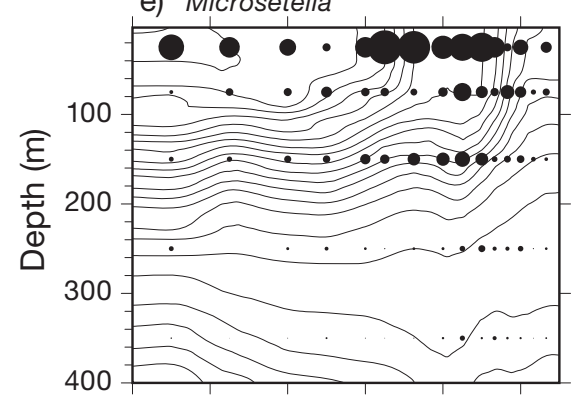

g) Oncaea
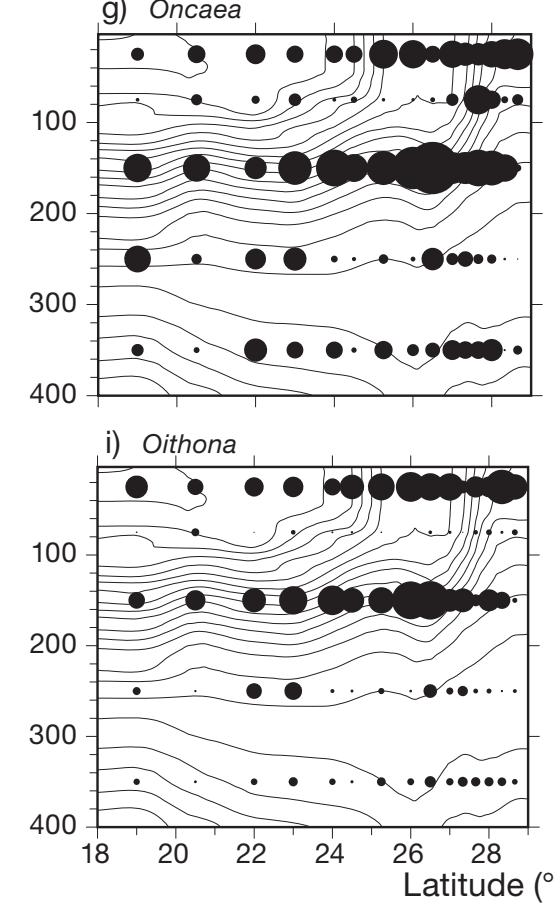

d) Calocalanus

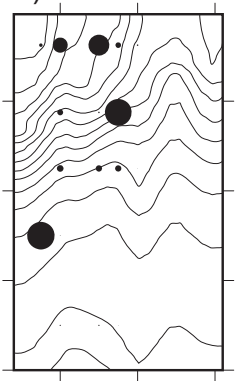

f) Microsetella

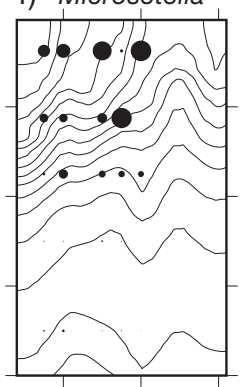

h) Oncaea
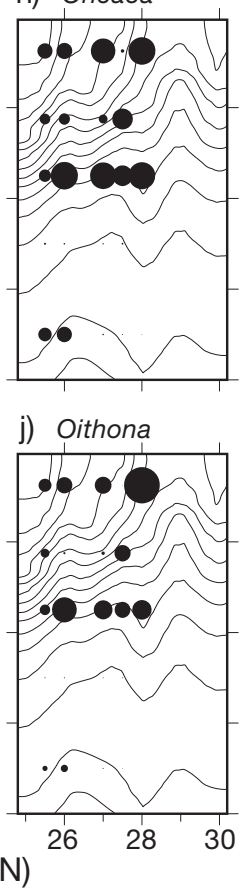

layers, while others peaked in subsurface layers in association with the subsurface chl a peak.

\section{The protozoans: heterotrophic dinoflagellates as key grazers}

Dinoflagellate biomass exceeded that in previous investigations in oligotrophic waters by a factor of roughly 3 (Lessard \& Murrell 1996, Nielsen et al. 2004). In fact, the potential secondary production of the dominant protozoan, the heterotrophic dinoflagellate Gymnodinium spirale, exceeds that of the entire copepod secondary production (Fig. 8). In contrast to Lessard \& Murrell (1996), we found a dominance by dinoflagellates over ciliates in the Sargasso Sea.

The ciliate biomass was, however, similar to previous observations in the Sargasso Sea and other oligotrophic waters. Nevertheless, because ciliates have higher metabolic rates (Hansen et al. 1997), the 2 groups contribute equally to the carbon cycling and the protozoan production (Table 4, Fig. 8). Dinoflagellate feeding on pico-sized bacterioplankton appears controversial (Strom 1991, Hansen et al. 1997, Jeong et al. 2005); however, we suspect that in the Sargasso Sea the dinoflagellates feed mainly on larger particles such as aggregated pico- and bacterioplankton, flagellates, diatoms and ciliates. It is important to note that we did not quantify the heterotrophic nanoflagellates, a key functional group in the microbial food web responsible for repacking the picoplankton and making this plankton fraction available to higher trophic levels (VázquezDomínguez et al. 2008).

\section{The copepod community: dominance of small species}

The high spatial resolution combined with the application of a $50 \mu \mathrm{m}$ mesh size provide substantial new information about the composition and horizontal distribution of metazooplankton in the southern Sargasso Sea and its relation to the oceanographic features of the STCZ. At Transect 1, abundance in the pycnocline of all the major zooplankton groups was highest in the central part of the STCZ. Previous studies have overlooked this response in zooplankton abundance in relation to the frontal structure, probably owing to the use of plankton nets with coarse mesh and/or sampling

Fig. 5. Depth distribution of the dominant copepod species $\left(\mathrm{m}^{-3}\right)$ illustrated by relative area of circles along Transects 1 and 3 superimposed on the temperature distribution (isotherms): (a,b) Clausocalanus, (c,d) Calocalanus, (e,f) Microsetella, $(\mathrm{g}, \mathrm{h})$ Oncaea and $(\mathrm{i}, \mathrm{j})$ Oithona 


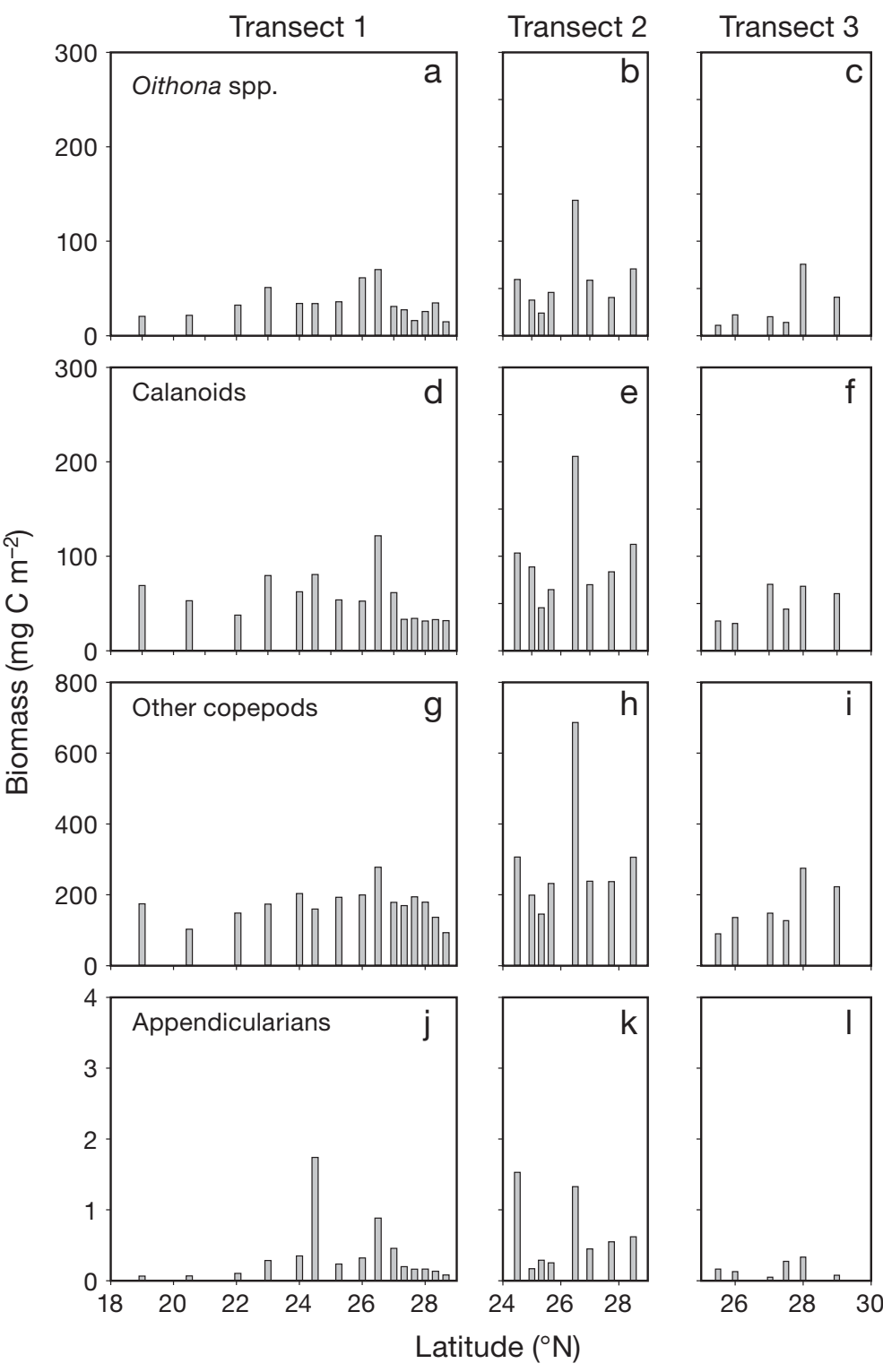

Fig. 6. Integrated copepod (a-i) and appendicularian ( $\mathrm{j}-\mathrm{l})$ biomass in the upper $400 \mathrm{~m}$ at Transects 1 and 3, and in $250 \mathrm{~m}$ at Transect 2

without considering the water column structure in the sampling program (Colton et al. 1975, Böttger 1982).

The diverse copepod assemblage accounted for $95 \%$ of the total metazooplankton abundance. Fisher's diversity index showed no significant difference between the south, the middle and the north of the front. The number of species in the STCZ was higher than observed in earlier studies presumably owing to our use of a small mesh size $(50 \mu \mathrm{m})$. For example, we identified almost 50 species of copepods in the surface stratum while earlier studies in the Sargasso Sea that used coarser mesh sizes only identified about half of this number (Sutcliffe 1960, Colton et al. 1975). However, our investigation corroborates previous studies
(Hopcroft et al. 1998a, 2001, Satapoomin et al. 2004) emphasizing the importance of including the size fraction $<200 \mu \mathrm{m}$ if the diversity and biomass of copepods in oligotrophic areas, like the Sargasso Sea, is to be fully represented.

The measured copepod biomass is similar to oligotrophic waters off Jamaica (Webber \& Roff 1995) and marginally $(14 \%)$ lower than in the oligotrophic Andaman Sea, Indian Ocean (Satapoomin et al. 2004). Hence, even though the standing stock of copepods in the STCZ is elevated compared with the adjacent more stratified waters, abundance is not particularly high relative to what generally is observed for oligotrophic waters.

\section{Appendicularians}

Traditionally, copepods are considered the most important metazooplankton group in pelagic food webs, while the more fragile appendicularians are the second most abundant metazooplankton group when appropriate sampling gear is employed (Hopcroft \& Roff 1998a, Jaspers et al. 2009). Owing to their specialised feeding mode, appendicularians are able to directly exploit the picoplankton-dominated primary production, while copepods are dependent on protozoans as intermediates to access the primary producers. Therefore, the 'larvacean shunt' (Deibel \& Lee 1992) short-circuits the food web and directly transfers energy to higher trophic levels. Interestingly, larvacean abundance was highly connected to the STCZ in both the surface layers and in the pycnocline (Fig. $4 \mathrm{~g}, \mathrm{~h}$ ). This is especially interesting because these organisms have been suggested as potential food for eel larvae (Mochioka \& Iwamizu 1996). Even though they only constituted $~ 1 \%$ by numbers of the total zooplankton community in the present study, they are known to have high production rates (Hopcroft \& Roff 1998a, Sato et al. 2003).

\section{The potential growth of metazooplankton}

Our study provides new information to the limited knowledge about growth rates of copepods in oligotrophic waters. Similar to findings by Kiørboe \& Sabatini (1994), juvenile calanoids had higher growth (specific 

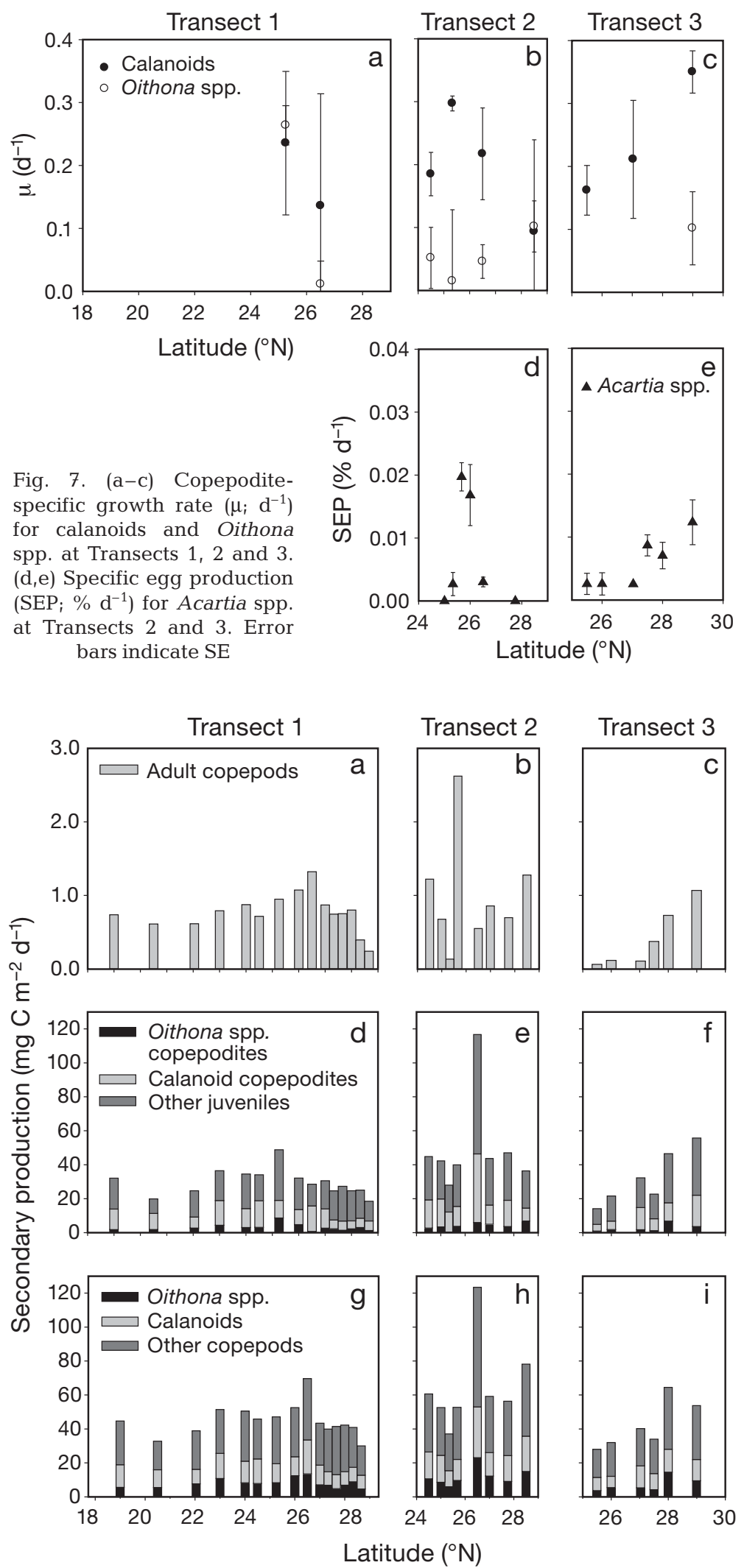

Fig. 8. Secondary production ( $\mathrm{mg} \mathrm{C} \mathrm{m} \mathrm{C}^{-1}$ ) by the copepod community: $(\mathrm{a}-\mathrm{c})$ adults and $(\mathrm{d}-\mathrm{f})$ juveniles. $(\mathrm{g}-\mathrm{i})$ Secondary production calculated from Hirst \& Bunker (2003) for the 3 transects growth rate: 0.09 to $0.35 \mathrm{~d}^{-1}$ ) than did juvenile cyclopoid Oithona spp. (0.01 to $0.26 \mathrm{~d}^{-1}$ ). Similar rates have been measured off Jamaica (Hopcroft et al. 1998b) and Great Barrier Reef in waters having the same chl a concentration (De Gusmao \& McKinnon 2007). But growth rates for Oithona were about twice as high as we found $(0.37$ to $0.35 \mathrm{~d}^{-1}$ ) and much higher growth rates in Stages 1 to 3 were measured for Paracalanus and Clausocalanus (1.49 to $0.83 \mathrm{~d}^{-1}$ ) in other oceanic areas with the same levels of chl $a$ and temperature as found in our study (Webber \& Roff 1995). However, the differences between our study and those other investigations may reflect differences in methodology.

To verify the measured growth rates by independent methodology, we also calculated the clearance rate from the growth rates and the food concentrations, assuming that one-third of the ingested food is realized as growth by the copepodites (Table 5). Clausocalanus was a dominant genus in the calanoid group (Fig. 4) and the mean calculated clearance rate corresponds closely to the clearance rate for Clausocalanus furcatus $\left(48 \mathrm{ml}\right.$ ind. ${ }^{-1} \mathrm{~d}^{-1}$, Mazzocchi \& Paffenhöfer 1999). Oithona spp. clearance rate was significantly lower than for the calanoids, but similar to the observed clearance rate in the laboratory for Oithona davisae of 2 to $12 \mathrm{ml}$ ind..$^{-1} \mathrm{~d}^{-1}$ (Saiz et al. 2003). The adult Acartia spp. had the same clearance rate as the juvenile Oithona spp. (Table 5). The clearance rate of Acartia spp. appears low (Berggreen et al. 1988), probably due to the small prey size in the Sargasso Sea. Overall, the calculated clearance rates are within the range measured in laboratory experiments.

The mean specific egg production rate was an order of magnitude lower than the copepodite growth rate. The egg production method has been suggested to give estimates of growth representative for the entire copepod population (Peterson et al. 1991). However, egg production may only be comparable with juvenile growth in small species, owing to ontogenetically increased food limitation in larger species (Hopcroft \& Roff 1998b, Hirst \& Bunker 2003). But even though egg production does not reflect growth of the entire copepod population, the method is still a good proxy for indentifying areas of high secondary production (Kiørboe 
Table 3. Secondary production (mean \pm SD) measured in the present study and calculated using the equations from Hirst \& Bunker (2003). Different measures of growth multiplied by the biomass. Production calculated from specific egg production (SEP) is $8 \pm 0.1 \%$ of that calculated on the basis of juvenile growth and SEP. Production calculated after Hirst \& Bunker (2003) overestimates the production by $20 \pm 2.6 \%$ compared with that calculated on the basis of juvenile growth and SEP

\begin{tabular}{|lcccc|}
\hline Production $\left(\mathrm{mg} \mathrm{C} \mathrm{m}^{-2} \mathrm{~d}^{-1}\right.$ ) & South of STCZ & STCZ & North of STCZ \\
\hline Calculated on the basis of SEP & $2.9 \pm 1$ & $3.1 \pm 3$ & $3.3 \pm 1$ & $8 \pm 0.1$ \\
On the basis of juvenile growth and SEP & $37 \pm 11$ & $40 \pm 28$ & $43 \pm 17$ & 100 \\
Calculated from Hirst \& Bunker (2003) & $44 \pm 7$ & $51 \pm 24$ & $54 \pm 17$ & $120 \pm 2.6$ \\
\hline
\end{tabular}
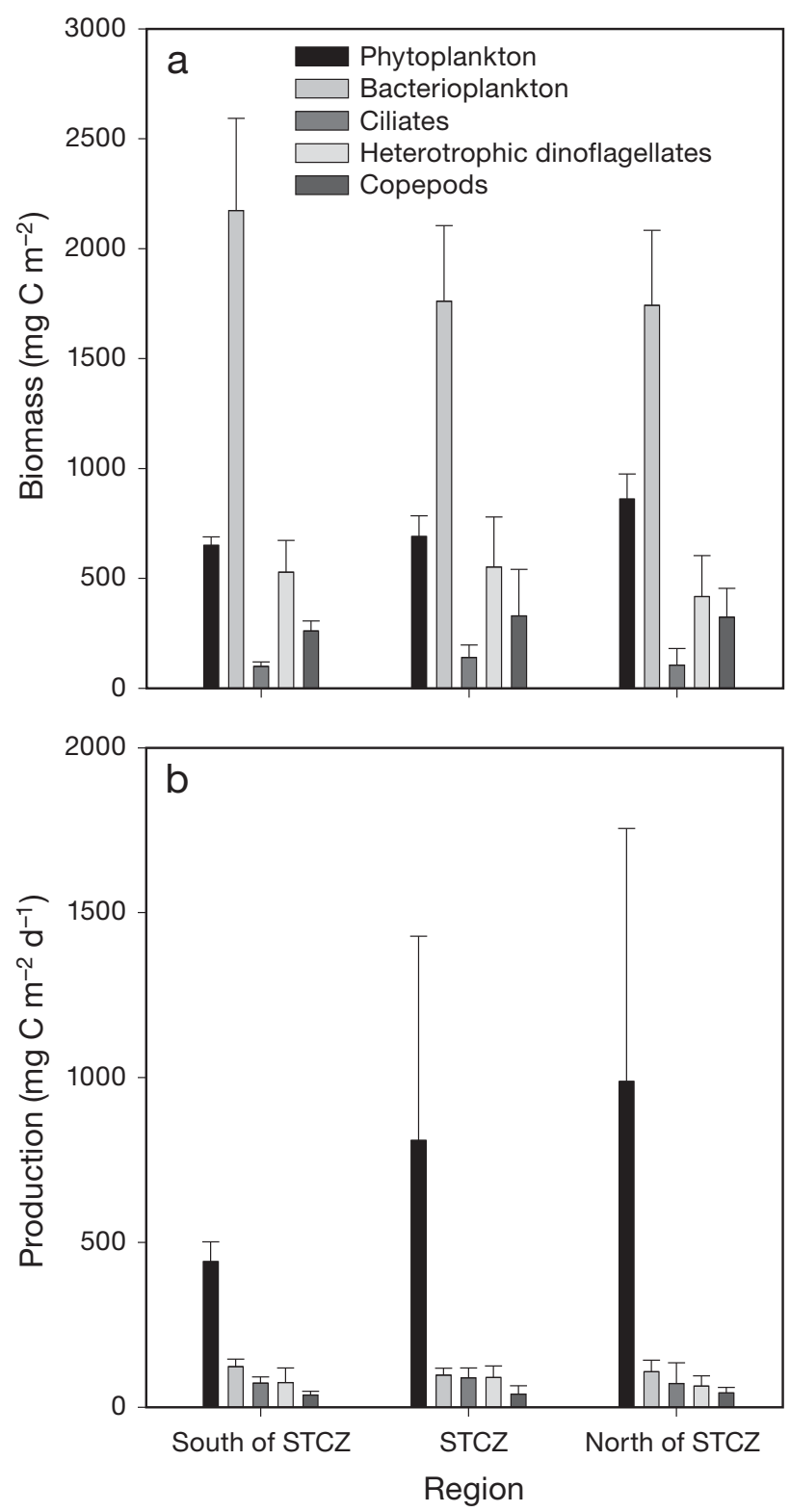

Fig. 9. (a) Biomass $\left(\mathrm{mg} \mathrm{C} \mathrm{m}^{-2}\right)$ and (b) production $\left(\mathrm{mg} \mathrm{C} \mathrm{m}^{-2} \mathrm{~d}^{-1}\right)$ of the major compartments of the Sargasso Sea across the subtropical convergence zone (STCZ) integrated over the upper $400 \mathrm{~m}$ (means $\pm \mathrm{SD}$ ). Data on primary production and bacterial biomass and production originate from Riemann et al. (2011, this volume)
\& Johansen 1986, Tester \& Turner 1990, Satapoomin et al. 2004). No features in the surface chl a or protozoans $>4 \mu \mathrm{m}$ could explain the higher specific egg production at the middle of Transect 2, except for the higher fraction of phytoplankton $>10 \mu \mathrm{m}$ at Stn 21 (Riemann et al. 2011).

\section{Potential grazing impact by the zooplankton community}

The role of dinoflagellates as grazers is often ignored. Here we documented that the potential grazing of dinoflagellates equals that of ciliates, and that the estimated daily grazing impact of protozoans (dinoflagellates and ciliates) on the primary production adds up to ca. $86 \% \mathrm{~d}^{-1}$, which is several times higher than for the copepods (Table 4). This estimate is high but within the range measured by dilution experiments in the Sargasso Sea (Lessard \& Murrell 1996) and comparable with values for subtropical oceans in general (Calbet \& Landry 2004). Moreover, our study indicates that Gyrodinium spirale is a key species in the protozoan community emphasising the need to address its ecological role in future studies. Recently Calbet \& Landry (2004) documented the global significance of microzooplankton grazing on the primary production based on dilution experiments. Owing to the wide application of the dilution technique, the relative role of different microzooplankton groups is not often resolved. Our estimates are based on quantification by means of microscopy of the 2 main contributors, heterotrophic ciliates and dinoflagellates, and the empirical relations from Hansen et al. (1997) allowing the separation of the 2 very different functional groups, the cilates and the heterotrophic dinoflagellates (Hansen et al. 1994).

The grazing impact of the copepod community can be evaluated by comparison with the standing stock of phytoplankton and primary production (see data from the accompanying paper by Riemann et al. 2011). The copepods grazed $15 \pm 4 \%$ of the phytoplankton biomass and $18 \pm 2 \%$ of the primary production per day (Table 4). Considering the predomi- 
Table 4. Potential grazing of copepods and protozoans on phytoplankton biomass (PB) and primary production (PP) in \% $\mathrm{d}^{-1}$ for the south, middle and north of the STCZ. Values are means \pm SD

\begin{tabular}{|lcccc|}
\hline Grazing & $\begin{array}{c}\text { South of } \\
\text { STCZ }\end{array}$ & STCZ & $\begin{array}{c}\text { North of } \\
\text { STCZ }\end{array}$ & Mean \\
\hline Copepods on PB & $17 \pm 4$ & $16 \pm 11$ & $15 \pm 7$ & $16 \pm 8$ \\
Copepods on PP & $27 \pm 7$ & $56 \pm 91$ & $20 \pm 1$ & $40 \pm 63$ \\
$\begin{array}{l}\text { Ciliates on PB } \\
\text { Ciliates on PP }\end{array}$ & $29 \pm 15$ & $37 \pm 17$ & $36 \pm 18$ & $34 \pm 3$ \\
$\begin{array}{l}\text { Heterotrophic dino- } \\
\text { flagellates on PB }\end{array}$ & $34 \pm 241$ & $36 \pm 16$ & $31 \pm 20$ & $43 \pm 17$ \\
$\begin{array}{c}\text { Heterotrophic dino- } \\
\text { flagellates on PP }\end{array}$ & $78 \pm 43$ & $47 \pm 40$ & $42 \pm 46$ & $56 \pm 20$ \\
\hline
\end{tabular}

Table 5. Average clearance rates calculated by assuming specific growth and specific egg production is one-third of the ingestion rate. Means $\pm \mathrm{SD}$

\begin{tabular}{|lcr|}
\hline & $\begin{array}{c}\text { Clearance rate } \\
\left(\mathrm{ml} \mathrm{ind}^{-1} \mathrm{~d}^{-1}\right)\end{array}$ & $\mathrm{n}$ \\
\hline $\begin{array}{l}\text { Adult Acartia spp. } \\
\text { Paracalanus, Clausocalanus and }\end{array}$ & $15.1 \pm 0.7$ & 11 \\
$\begin{array}{l}\text { Calocalanus spp. copepodites } \\
\text { Oithona spp. copepodites }\end{array}$ & $15.9 \pm 9.0$ & 9 \\
\hline
\end{tabular}

nance of chl $a$ in the $<10 \mu \mathrm{m}$ size fraction and that the phytoplankton was dominated by picoplankton (i.e. $<2 \mu \mathrm{m}$, Riemann et al. 2011), copepods must be disproportionately consuming the larger primary producers. While picoplankton detritus may be efficiently grazed by protozoans and zooplankton, most of the picoplankton is presumably unavailable to copepods (Hansen et al. 1994). Hence, the observed copepod grazing rates may support the assumption of an important role of protozoans linking picoplanktonic primary production to higher trophic levels.

The production of the copepod community (in mg C $\mathrm{m}^{-2} \mathrm{~d}^{-1}$ ) did not show any significant change across the STCZ (Fig. 7). Production calculated on the basis of specific egg production underestimated the production on basis of both copepodite growth and egg production by $92 \%$ (Table 3). Similar results were obtained in open water off Jamaica (Hopcroft \& Roff 1998b). The Hirst \& Bunker (2003) proxy, including data on chl a, temperature and copepod body weight to predict secondary production (Eq. 8), slightly overestimated copepod total production by $20 \%$ relative to our measurements (Table 3).

The present investigation points to a pivotal role for ciliates and specifically for heterotrophic dinoflagellates in the Sargasso Sea pelagic food web, in particular with respect to making the picoplankton- dominated primary production available to the copepods. The production of these 2 groups alone could cover the carbon need of the copepod community. Owing to the presence of larval Atlantic eels in the central areas of the STCZ (Munk et al. 2010), we hypothesized that this area would be particularly productive. Even though elevated levels of chl a were observed to be associated with the thermal fronts bordering the STCZ (Riemann et al. 2011), the standing stock of zooplankton and, in particular, the secondary production at the sampled stations within the STCZ did not consistently show elevated levels. However, specific taxonomic groups, such as the subsurface population of appendicularians (Fig. 4g,h) and the particle-associated copepod genus Oncaea, showed peak densities in the central STCZ. Hence, the beneficial conditions to Atlantic eel larvae in their area of distribution might not lie in an enhanced productivity, but more in the abundance of specific favoured prey items.

Acknowledgements. The project was supported by grants from the Villum Kann Rasmussen Foundation, Elisabeth \& Knud Petersen's Foundation, TK Holding and the Rod and Net fishing Licensee. P. J. Hansen and H. U. Riisgård are thanked for constructive comments on an earlier version of the manuscript. The present work was carried out as part of the Galathea 3 Expedition under the auspices of the Danish Expedition Foundation. This is Galathea 3 contribution no. P76.

\section{LITERATURE CITED}

Berggreen U, Hansen B, Kiørboe T (1988) Food size spectra, ingestion and growth of the copepod Acartia tonsa during development: implications for determination of copepod production. Mar Biol 99:341-352

Böttger R (1982) Studies on the small invertebrate plankton of the Sargasso Sea. Helgol Meeresunters 35:369-383

Calbet A, Landry MR (1999) Mesozooplankton influences on the microbial food web: Direct and indirect trophic interactions in the oligotrophic open ocean. Limnol Oceanogr 44:1370-1380

Calbet A, Landry MR (2004) Phytoplankton growth, microzooplankton grazing, and carbon cycling in marine systems. Limnol Oceanogr 49:51-57

Calbet A, Landry MR, Scheinberg RD (2000) Copepod grazing in a subtropical bay: species-specific responses to a midsummer increase in nanoplankton standing stock. Mar Ecol Prog Ser 193:75-84

Chisholm LA, Roff JC (1990) Size-weight relationships and biomass of tropical neritic copepods off Kingston, Jamaica. Mar Biol 106:71-77

Colton J, Smith DE, Jossi JW (1975) Further observations on a thermal front in the Sargasso Sea. Deep-Sea Res I 22: 433-439

De Gusmao L, McKinnon A (2007) Mesozooplankton biomass 
and copepod growth rates in the Whitsunday Islands, Great Barrier Reef, Australia. 4th Int Zooplankton Production Symp, Hiroshima, Japan, 28 May-1 Jun 2007

> Deevey GB (1971) The annual cycle in quantity and composition of the zooplankton of the Sargasso Sea off Bermuda. 1. The upper $500 \mathrm{~m}$. Limnol Oceanogr 16:219-240

$>$ Deevey GB, Brooks AL (1971) The annual cycle in quantity and composition of the zooplankton of the Sargasso Sea off Bermuda. II. The surface to 2000 m. Limnol Oceanogr 16:927-943

Deibel D, Lee SH (1992) Retention efficiency of submicrometer particles by the pharyngeal filter of the pelagic tunicate Oikopleura vanhoeffeni. Mar Ecol Prog Ser 81:25-30

> Eden BR, Steinberg DK, Goldthwait SA, McGillicuddy D J (2009) Zooplankton community structure in a cyclonic and mode-water eddy in the Sargasso Sea. Deep-Sea Res I 56: $1757-1776$

Gasol JM, del Giorgio PA, Duarte CM (1997) Biomass distribution in marine planktonic communities. Limnol Oceanogr 42:1353-1363

- Halliwell GR, Peng G, Olson DB (1994) Stability of the Sargasso Sea Subtropical Frontal Zone. J Phys Oceanogr 24: 1166-1183

Hansell DA, Carlson CA (2001) Biogeochemistry of total organic carbon and nitrogen in the Sargasso Sea: control by convective overturn. Deep-Sea Res II 48:1649-1667

Hansen B, Bjørnsen PK, Hansen PJ (1994) The size ratio between planktonic predators and their prey. Limnol Oceanogr 39:395-403

> Hansen PJ, Bjørnsen PK, Hansen BW (1997) Zooplankton grazing and growth: scaling within the $2-2,000 \mu \mathrm{m}$ body size range. Limnol Oceanogr 42:687-704

Hirst AG, Bunker AJ (2003) Growth of marine planktonic copepods: global rates and patterns in relation to chlorophyll $a$, temperature, and body weight. Limnol Oceanogr 48:1988-2010

> Hopcroft RR, Roff JC (1998a) Production of tropical appendicularians in Kingston Harbour, Jamaica: Are we ignoring an important secondary producer? J Plankton Res 20: 557-569

> Hopcroft RR, Roff JC (1998b) Zooplankton growth rates: the influence of female size and resources on egg production of tropical marine copepods. Mar Biol 132:79-86

> Hopcroft RR, Roff JC, Lombard D (1998a) Production of tropical copepods in Kingston Harbour, Jamaica: the importance of small species. Mar Biol 130:593-604

> Hopcroft RR, Roff JC, Webber MK, Witt JDS (1998b) Zooplankton growth rates: the influence of size and resources in tropical marine copepodites. Mar Biol 132:67-77

> Hopcroft RR, Chavez FP, Roff JC (2001) Size paradigms in copepod communities: a re-examination. Hydrobiologia 453/454:133-141

ICES (2006) Reports of the Eifac/ICES Working Group on Eels, Rome, Italy. International Council for Exploration of the Sea, Copenhagen, ICES CM 2006/ACFM 16, Ref. DFC, LRC, RMC: 101

> Jaspers C, Nielsen TG, Carstensen J, Hopcroft RR, Møller EF (2009) Metazooplankton distribution across the Southern Indian Ocean with emphasis on the role of larvaceans. J Plankton Res 31:525-540

> Jeong HJ, Du Yoo Y, Park JY, Song JY and others (2005) Feeding by phototrophic red-tide dinoflagellates: five species newly revealed and six species previously known to be mixotrophic. Aquat Microb Ecol 40:133-150

Kimmerer WJ, McKinnon AD (1987) Growth, mortality, and secondary production of the copepod Acartia tranteri in Westernport Bay, Australia. Limnol Oceanogr 32:14-28
Kimmerer WJ, Hirst AG, Hopcroft RR, McKinnon AD (2007) Estimating juvenile copepod growth rates: corrections, inter-comparisons and recommendations. Mar Ecol Prog Ser 336:187-202

Kiørboe T, Johansen K (1986) Studies of a larval herring (Clupea harengus L.) patch in the Buchan area. 4. Zooplankton distribution and productivity in relation to hydrographic features. Dana 6:37-51

Kiørboe T, Sabatini M (1994) Reproductive and life cycle strategies in egg-carrying cyclopoid and free-spawning calanoid copepods. J Plankton Res 16:1353-1366

Kiørboe T, Møhlenberg F, Hamburger K (1985) Bioenergetics of the planktonic copepod Acartia tonsa: relation between feeding, egg production and respiration, and composition of specific dynamic action. Mar Ecol Prog Ser 26: 85-97

Lessard EJ, Murrell MC (1996) Distribution, abundance and size composition of heterotrophic dinoflagellates and ciliates in the Sargasso Sea near Bermuda. Deep-Sea Res I 43:1045-1065

Lessard EJ, Murrell MC (1998) Microzooplankton herbivory and phytoplankton growth in the northwestern Sargasso Sea. Aquat Microb Ecol 16:173-188

Madin LP, Horgan EF, Steinberg DK (2001) Zooplankton at the Bermuda Atlantic Time-series Study (BATS) station: diel, seasonal and interannual variation in biomass, 19941998. Deep-Sea Res II 48:2063-2082

Malone TC, Pike SE, Conley DJ (1993) Transient variations in phytoplankton productivity at the JGOFS Bermuda time series station. Deep-Sea Res II 40:903-924

Mazzocchi M, Paffenhöfer G (1999) Swimming and feeding behaviour of the planktonic copepod Clausocalanus furcatus. J Plankton Res 21:1501-1518

> McGillicuddy DJ Jr, Robinson AR, Siegel DA, Jannasch HW and others (1998) Influence of mesoscale eddies on new production in the Sargasso Sea. Nature 394:263-266

Menden-Deuer S, Lessard EJ (2000) Carbon to volume relationships for dinoflagellates, diatoms, and other protist plankton. Limnol Oceanogr 45:569-579

Mochioka N, Iwamizu M (1996) Diet of anguilloid larvae: leptocephali feed selectively on larvacean houses and fecal pellets. Mar Biol 125:447-452

> Munk P, Maes GE, Hansen MM, Nielsen TG and others (2010) Oceanic fronts in the Sargasso Sea control the early life and drift of Atlantic eels. Proc R Soc B Biol Sci 277: 3593-3599

Nielsen TG, Bjørnsen PK, Boonruang P, Fryd M and others (2004) Hydrography, bacteria and protist communities across the continental shelf and shelf slope of the Andaman Sea (NE Indian Ocean). Mar Ecol Prog Ser 274: 69-86

> Palter JB, Lozier MS, Barber RT (2005) The effect of advection on the nutrient reservoir in the North Atlantic subtropical gyre. Nature 437:687-692

Peterson WT, Tiselius P, Kiørboe T (1991) Copepod eggproduction, molting and growth-rates, and secondary production, in the Skagerrak in August 1988. J Plankton Res 13:131-154

Platt T, Harrison WG, Lewis MR, Li WKW, Sathyendranath S, Smith RE, Vezina AF (1989) Biological production of the oceans: the case for a consensus. Mar Ecol Prog Ser 52: 77-88

Riemann L, Alfredsson H, Hansen MM, Als TD and others (2010) Qualitative assessment of the diet of European eel larvae in the Sargasso Sea resolved by DNA barcoding. Biol Lett 6:819-822

Riemann L, Nielsen TG, Kragh T, Richardson K, Parner H, 
Jakobsen HH, Munk P (2011) Distribution and production of plankton communities in the subtropical convergence zone of the Sargasso Sea. I. Phytoplankton and bacterioplankton. Mar Ecol Prog Ser 426:57-70

Saiz E, Calbet A, Broglio E (2003) Effects of small-scale turbulence on copepods: the case of Oithona davisae. Limnol Oceanogr 48:1304-1311

Satapoomin S, Nielsen T, Hansen P (2004) Andaman Sea copepods: spatio-temporal variations in biomass and production, and role in the pelagic food web. Mar Ecol Prog Ser 274:99-122

Sato R, Tanaka Y, Ishimaru T (2003) Species-specific house productivity of appendicularians. Mar Ecol Prog Ser 259: 163-172

Schlüter L, Henriksen P, Nielsen TG, Jakobsen HH (in press) Phytoplankton composition and biomass across the southern Indian Ocean. Deep-Sea Res

Steinberg DK, Carlson CA, Bates NR, Johnson RJ, Michaels AF, Knap AH (2001) Overview of the US JGOFS Bermuda Atlantic Time-series Study (BATS): a decade-scale look at ocean biology and biogeochemistry. Deep-Sea Res II 48: 1405-1447

Editorial responsibility: Edward Durbin, Narragansett, Rhode Island, USA
Strom SL (1991) Growth and grazing rates of the herbivorous dinoflagellate Gymnodinium sp. from the open subarctic Pacific Ocean. Mar Ecol Prog Ser 78:103-113

Sutcliffe WH (1960) On the diversity of the copepod population in the Sargasso Sea of Bermuda. Ecology 41:585-587

Tester PA, Turner JT (1990) How long does it take copepods to make eggs? J Exp Mar Biol Ecol 141:169-182

Tranter DJ (1976) Herbivore production. In: Cushing DH, Walsh JJ (eds) The ecology of the seas. Blackwell Scientific, Oxford, p 186-224

Utermöhl H (1958) Zur Vervollkommnung der quantitativen Phytoplankton-Methodik. Mitt Int Ver Theor Angew Limnol 9:1-38

Vázquez-Domìnguez E, Duarte CM, Agustì S, Jürgens $\mathrm{K}$, Vaqué D, Gasol JM (2008) Microbial plankton abundance and heterotrophic activity across the Central Atlantic Ocean. Prog Oceanogr 79:83-94

Voorhis AD, Hersey JB (1964) Oceanic thermal fronts in Sargasso Sea. J Geophys Res 69:3809

Webber M, Roff J (1995) Annual biomass and production of the oceanic copepod community off Discovery Bay, Jamaica. Mar Biol 123:481-495

Submitted: June 3, 2010; Accepted: January 20, 2011 Proofs received from author(s): March 6, 2011 